\title{
Parque Central: recorrido virtual y construcción aleatoria
}

\author{
Nemesio Orellana, artista visual \\ nemesio.orellana@gmail.com
}

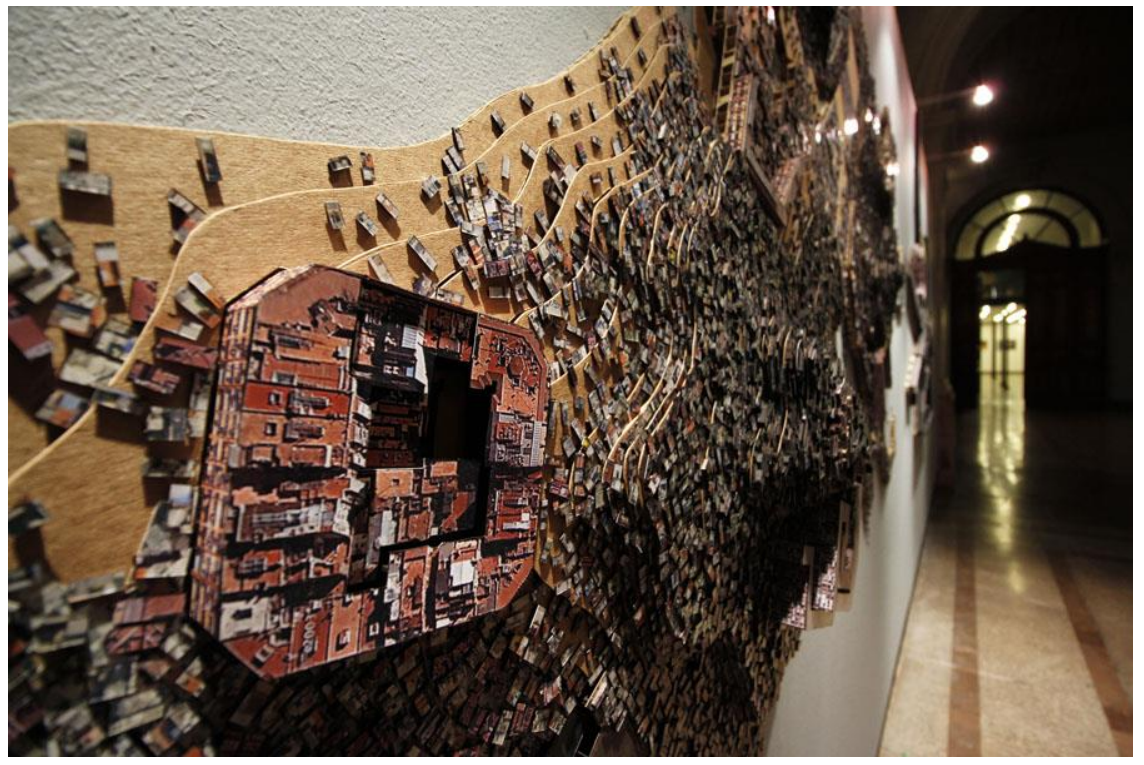

Todas las imágenes son de Nemesio Orellana, Parque Central, Centro Cultural Estación Mapocho, 2016.

Desde un extenso recorrido virtual (Google Earth), se realiza un ejercicio de captura y recolección de fotografías tomadas a una elevación promedio de 300 metros, haciéndose un simulacro por construir y ficcionar cruces entre distintas y contrastantes realidades urbanas por medio de patrones estandarizados, donde la forma y la racionalidad son suplantadas por pura proliferación, dando origen a una ciudad b trastornada, sin lógica ni coherencia, absurda y saturada. Una ciudad con múltiples referencias que se acoplan bajo la lógica de re-combinaciones inéditas de realidades pre existentes.

Por medio de la virtualidad de las imágenes se construye un lugar sin identidad, sin historia, espacio de paso, de tránsito, de lo demasiado lleno, redundante, zona de incertidumbre que no permite saber dónde parte o termina la ciudad; finalmente, un no-lugar. 


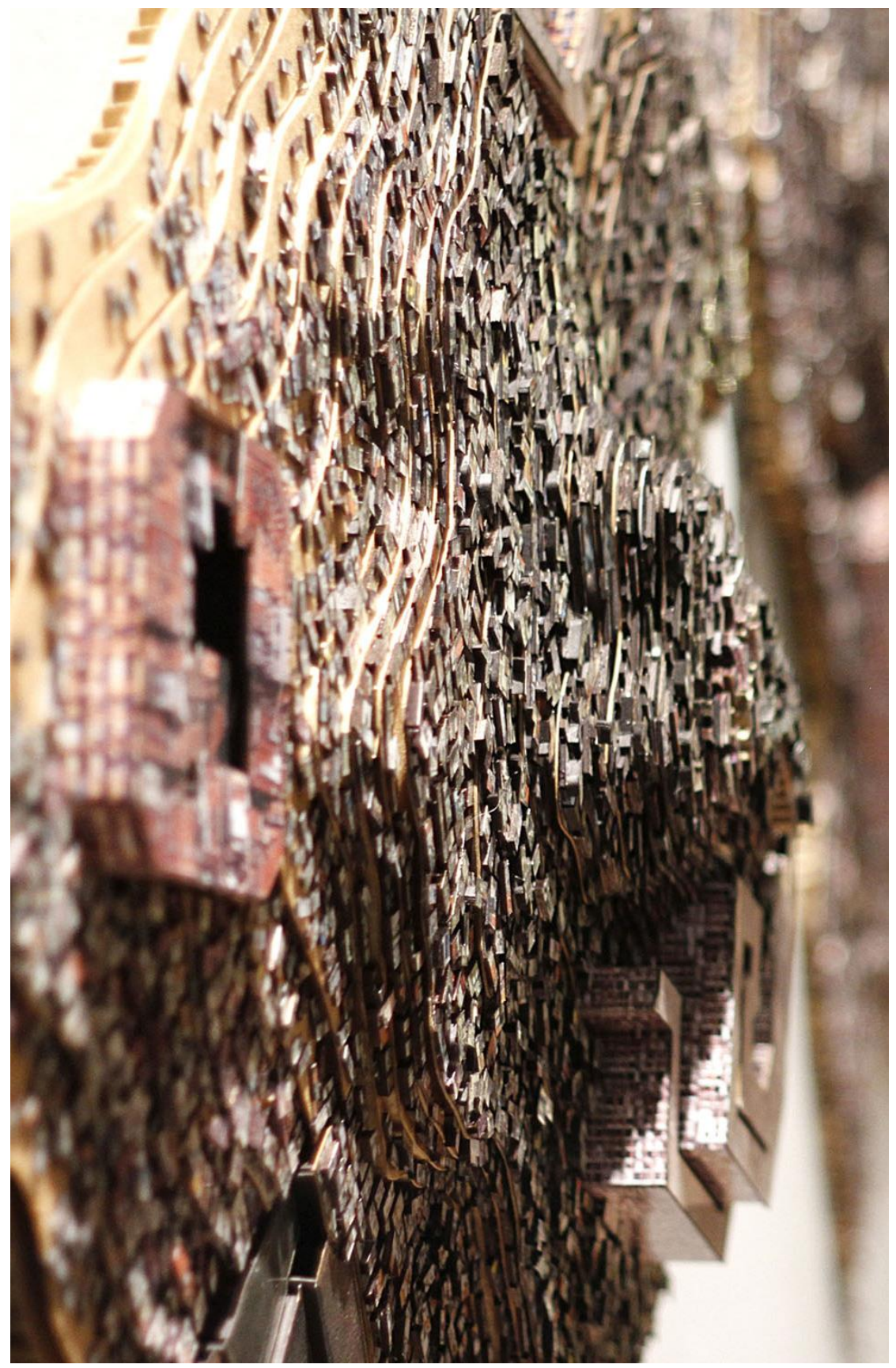




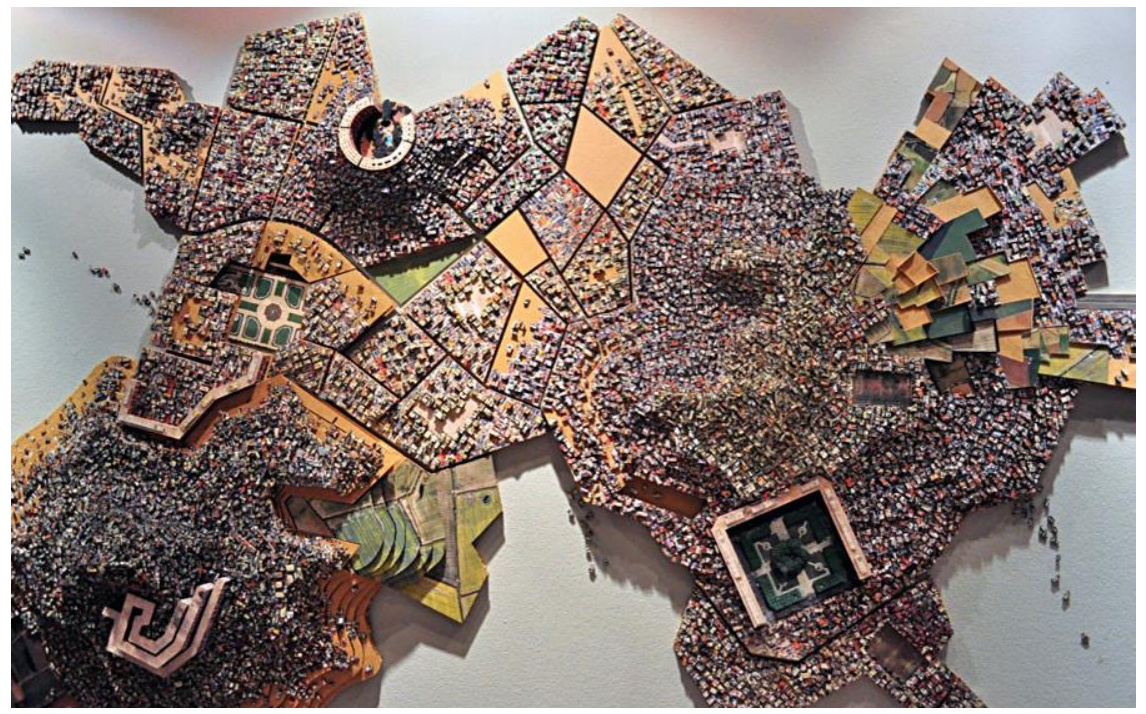

\section{Proliferación y forma urbana}

La ciudad como máquina y totalidad orgánica, como dispositivo de organización, da paso a una ciudad dislocada, donde la expansión de los suburbios, ranchos o poblaciones callampas, entendidos estos como un fracaso arquitectónico y urbano grave, se transforman en protagonistas y estructuradores de una ciudad conformada desde y por periferias.

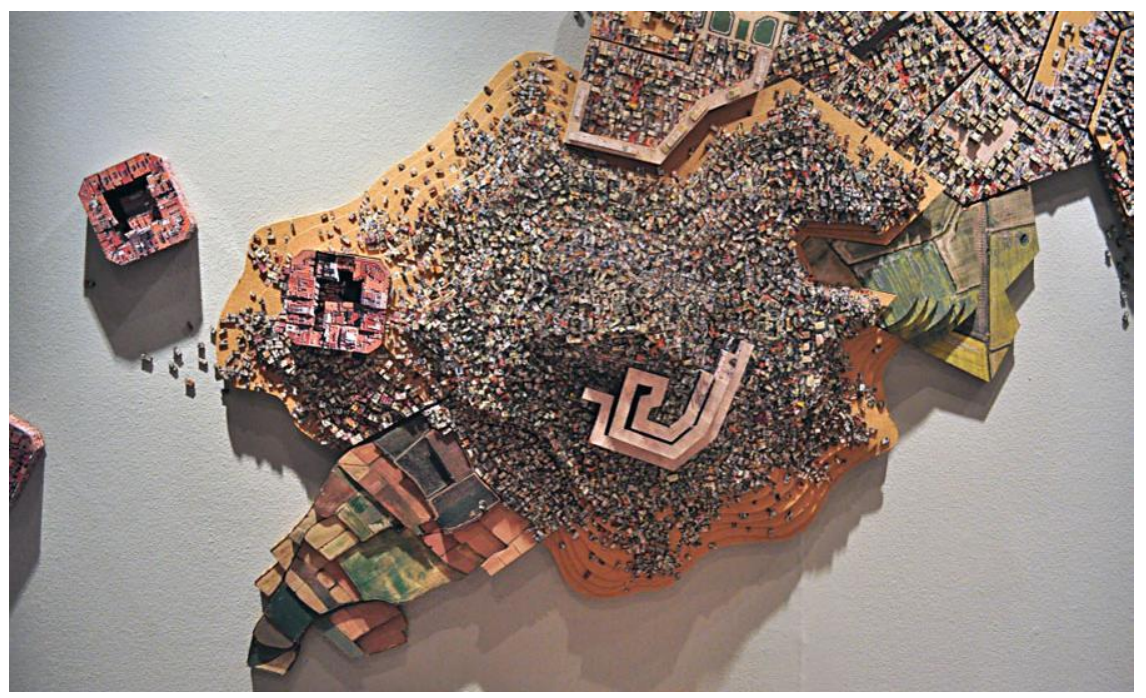



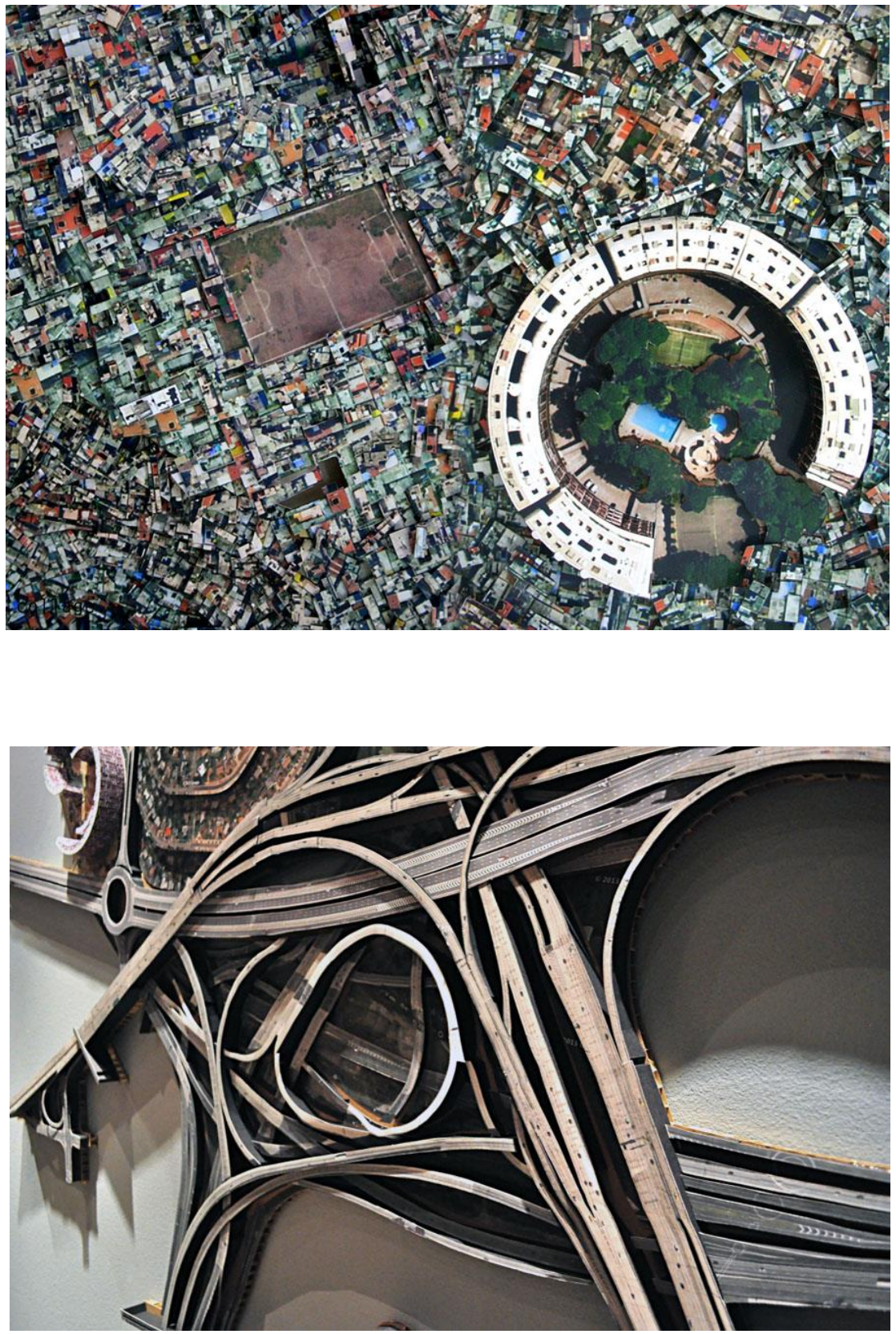
Panambí n. 2 Valparaíso jun. 2016 ISSN 0719-630X. 13-17.

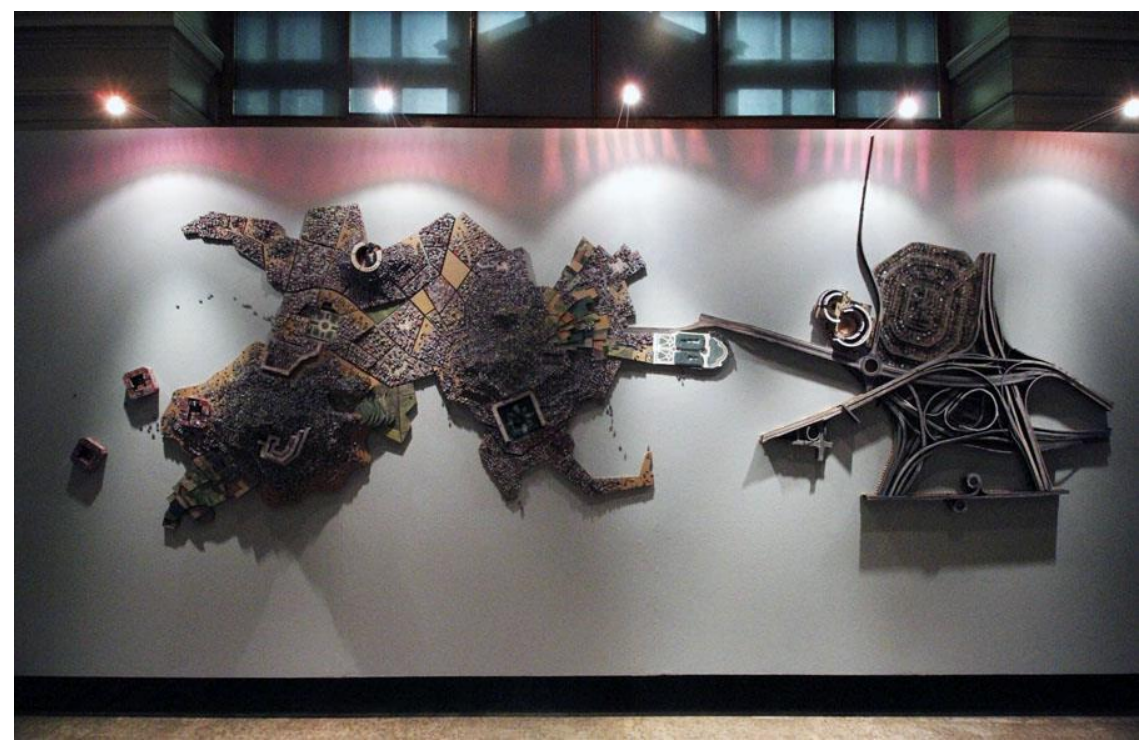

La situación de estar en tránsito se está volviendo universal.

Rem Koolhaas, La ciudad genérica, 2006 